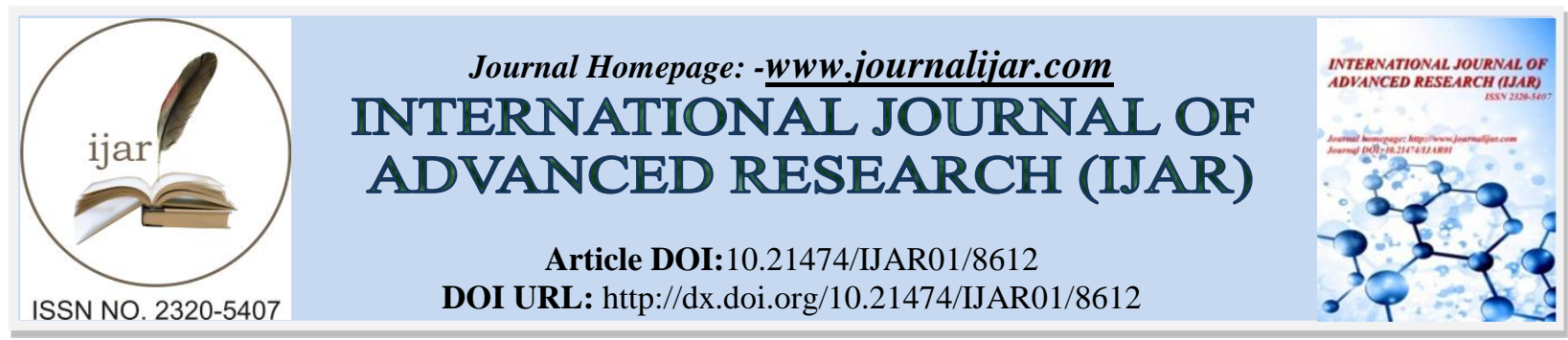

RESEARCH ARTICLE

\title{
KNOWLEDGE AND ATTITUDES AMONG SCHOOL TEACHERS TOWARDS SCHOOL STUDENTS WITH EPILEPSY IN HAIL REGION, KSA.
}

\author{
Syed Irfan Ali ${ }^{1}$,Wasmiah Marzouq Alshammari ${ }^{2}$, Amal Abdullah Abuqaisi ${ }^{2}$, Nada Raja Marzooq Alharbi ${ }^{2}$ \\ and Zaid Awad Hamoud Alshammari ${ }^{2}$. \\ 1. Neurology Consultant, King Khaled Hospital, Hail, KSA. \\ 2. Department of Neurology, Collage of medicine, University of Hail, KSA.
}

\section{Manuscript Info}

\section{Manuscript History}

Received: 04 January 2018

Final Accepted: 06 February 2019

Published: March 2019

Key words:-

Attitude; Beliefs; Epilepsy; Knowledge; Students; Teachers.

\begin{abstract}
Background: The knowledge and attitude of school teachers can affect significantly the academic achievement, social development and the quality of life of epileptic students.

Objective: To assess the knowledge and attitude of school teachers towards students with epilepsy in Hail, KSA.

Methods: This cross-sectional study used a pretested, selfadministered, 5-item questionnaire to evaluate the basic knowledge and attitude of Elementary, intermediate, and secondary schools' teachers as regards epilepsy. Schools were chosen at random and included private and public schools for male and female students.

Results: The study included 342 teachers. $98.8 \%$ of the respondents heard about the disease, with no significant association with age $(\mathrm{p}=$ $0.205)$ or gender $(p=0.593)$. The common reported causes for epilepsy included mental disease (62.6\%), spiritual possession (11.1\%), electric charges in the brain $(9.9 \%)$ and disturbed nerves $(5.3 \%) .71 .3 \%$ of respondents were willing to provide first aid during fits and objected to prevent epileptic students from studying (97.7\%). Age was significantly associated with knowledge about causes of epilepsy $(\mathrm{p}=$ $0.008)$ and readiness to provide first aid $(p=0.012)$. Gender was not significantly associated with neither knowledge nor attitude of the respondents.

Conclusion: Knowledge of teachers about causes of epilepsy was not adequate. Also, most of them would treat epileptic students differently from their peers. Educational programs should be provided to school teachers to correct wrong beliefs about epilepsy and to train them on first aid measures during epileptic fits.
\end{abstract}

Copy Right, IJAR, 2019,. All rights reserved.

\section{Introduction:-}

Epilepsy is one of the most common neurological disorders. It affects approximately 50 million people worldwide. ${ }^{1}$,

${ }^{2}$ The prevalence rate of epilepsy in Kingdom Saudi Arabia (KSA) was estimated to be $6.5 / 1000 .^{3}$ The disease is more prevalent in childhood, particularly in the first decade of life. ${ }^{4,5}$

Corresponding Author:-Syed Irfan Ali.

Address:-Neurology Consultant, King Khaled Hospital, Hail, KSA. 
Epileptic children have increased likelihood (by 2-5 times) of behavioral, emotional and psychiatric problems than healthy children or even children with other chronic diseases. ${ }^{6}$ Individuals with epilepsy are at a higher risk of developing psychiatric disorders such as depression, anxiety and psychosis. ${ }^{7}$ These problems are attributed to poor public knowledge about epilepsy as well as erroneous cultural beliefs that result in stigmatization of epileptic patients. ${ }^{8-10}$

Many people believe that epilepsy is contagious or may hinder learning, resulting in deprivation of many epileptic children from their rights of learning and normal social development. Also, inability of surrounding persons to deal appropriately with epileptic fits represents a serious hazard to the patients if their transport to professional medical care is delayed. ${ }^{11-14}$. All these factors affect negatively the quality of life of the epileptic children and their families. ${ }^{12}$

Children with epilepsy have the same range of intelligence and abilities as the rest of the population. ${ }^{15}$ The knowledge and attitude of school teachers can affect significantly the academic achievement, social development and the quality of life of epileptic students. ${ }^{16,17}$ Unfortunately, teachers usually do not have any formal training on dealing with epileptic children. ${ }^{18}$ Therefore, evaluation of teachers' knowledge and attitudes as regards epilepsy is essential to develop training programs that address any existent gaps.

Little research was conducted to assess teachers' knowledge and attitudes towards epilepsy in the KSA. ${ }^{19-21}$ Hence, the aim of this study was to investigate the knowledge and attitude of school teachers in Hail Region, KSA towards epilepsy.

\section{Methods:-}

\section{Ethical considerations:}

Approval was obtained from the principals of schools. The aim of the study was explained to teachers before participation and verbal consent was taken. The data were anonymous and confidential by assigning code numbers for each participant that is known only by the researchers.

\section{Study settings:}

This study was conducted in Hail region, KSA between September 2018 and January 2019.

\section{Study subjects:}

Inclusion criteria: participants of this study were school teachers Elementary, intermediate, and secondary schools Hail region, KSA. Both public and private schools were included, as well as schools dedicated for male or female children. The choice of schools was random.

Exclusion criteria: incomplete forms of the questionnaire were excluded.

\section{Study design:}

Cross-sectional.

\section{Sample size:}

Three hundred and forty-two teachers were included in the study.

Data collection methods, instrument used, and measurement:

The investigation tool was a self-administered questionnaire that was composed of two sections: section 1 included socio-demographic data relevant to the topic and section 2 included questions that were designed to measure knowledge and attitude towards epilepsy. The questionnaire was pretested on a pilot sample before distribution on the studied sample to ensure its clarity.

Data were collected during regular work time. Teachers were informed first about the study aim and were instructed how to fill the questionnaire appropriately.

\section{Statistical analysis:-}

Statistical analysis was conducted using SPSS software for windows, version 22. Categorical variables were summarized as frequencies and percentages. The association between the items of knowledge and attitude with 
sociodemographic characteristics was assessed using Pearson's Chi square test for independence, Fisher exact test or Fisher-Freeman-Halton exact test as appropriate. P-value less than 0.05 was considered as statistically significant.

\section{Results:-}

In this study, 342 teachers responded to the questionnaire. Table 1 summarizes the sociodemographic characteristics of the respondents. Teachers aged $25-35$ and $36-45$ accounted for $32.7 \%$ and $33.9 \%$, respectively. The vast majority were Saudi (99.4\%). Female teachers outnumbered the male teachers (68.4\% and $31.6 \%$, respectively).

Table 2 shows that the vast majority of respondents reported having heard about the disease (98.8\%), with no statistically significant difference between the age groups $(\mathrm{p}=0.205)$ or gender $(\mathrm{p}=0.593)$.

Figure 1 demonstrates the causes of epilepsy as reported by the respondents. The most frequent causes included mental disease $(62.6 \%)$, spiritual possession $(11.1 \%)$, electric charges in the brain $(9.9 \%)$ and disturbed nerves or nervous system $(5.3 \%)$.

Table 3 shows knowledge of the respondents about epilepsy causes. Only two respondents believed that epilepsy is contagious. There was a significant association between age of the respondents and their beliefs about the causes of epilepsy $(\mathrm{p}=0.008)$. A significantly higher proportion of all age groups thought epilepsy is a mental disease. A significant percentage of those who were aged above 45 years attributed epilepsy to spiritual possession (23.8\%) compared to the other age groups. There was no significant association between the respondents' knowledge about epilepsy and gender $(\mathrm{p}=0.979)$.

The attitude of the respondents towards epileptic students is shown in Table 4. About two thirds of respondents admitted that they would not treat epileptic children as their peers. Most respondents (71.3\%) stated that they would provide first aid during an epileptic fit. The majority (97.7\%) thought that epileptic students should not be prevented from studying. A significant association existed between age and the readiness to provide first aid during epileptic fits $(\mathrm{p}=0.012)$, as the highest percentage was in respondents aged more than 45 years old $(84 \%)$. There was no significant association between age and each of equal treatment or prevention from studying $(\mathrm{p}=0.063$ and 0.097$)$. Gender was not significantly associated with attitude $(\mathrm{p}=0.812,0.448$ and 0.984$)$.

\section{Discussion:-}

This study was conducted to investigate the knowledge and attitude of school teachers towards epilepsy in Hail Region, KSA. Only a limited number of studies have investigated this point in KSA in the regions of Jeddah ${ }^{19,21}$ and Khamis Mushate. ${ }^{20}$ Up to the best of the researchers' knowledge, the present study is the first of its type in Hail.

The vast majority of teachers in our study reported having heard about the disease (98.8\%). In agreement to this result, several studies stated that a high percentage of teachers $(70-97 \%)$ reported previous knowledge about epilepsy in Jeddah, $\mathrm{KSA}^{19,21}$ as well as in other countries including Korea, ${ }^{22}$ Turkey, ${ }^{23}$ India, ${ }^{24}$ Georgia, ${ }^{25}$ Nigeria, ${ }^{26}$ Pakistan, $^{27}$ and Iran. ${ }^{28}$

We found that the knowledge of teachers in our study about epilepsy and its causes was inadequate and showed many misconceptions such as epilepsy being a mental disease $(62.6 \%)$ or caused by spiritual possession (11.1\%). Similarly, one study in Jeddah, KSA found that spiritual possession or evil eye were reported by $27 \%$ and $22 \%$ of teachers as causes of epilepsy, ${ }^{21}$ while another study found that epilepsy was considered to be a psychiatric disease or a possession in $43.1 \%$ and $40.3 \%$ of school teachers. ${ }^{19}$

This confusion between mental illness, spiritual possession and epilepsy can be explained by examining the dominant culture in KSA. The Arabic word of "epilepsy" is "Saraa" and is used by some laypeople as a synonym for the word "jnoon" (insanity). Also, it is rooted in the culture of many Arabic countries that possession by "Jinn" could result in convulsions and disturbed consciousness which are the manifestations of epileptic fit ${ }^{29-31}$

A positive point was that almost all teachers in the present study (except for two) agreed that epilepsy is not contagious. In line with this finding, a study in Khamis Mushate, KSA found that most schoolteachers (82.2\%) believed that epilepsy was not infectious ${ }^{20}$. Also, studies in Turkey, ${ }^{23}$ Korea, $^{22}$ and India ${ }^{24}$ found only a small percentage of participating teachers $(0.6-3.3 \%)$ who believed epilepsy to be infectious. 
Investigation of the potential effect of age and gender on teachers' knowledge revealed that age - but not gender was significantly associated with knowledge about causes of epilepsy. A significant percentage of teachers aged above 45 years in our study attributed epilepsy to spiritual possession compared to the other age groups. This could be explained by susceptibility of older people in general to retain cultural beliefs, while the youth may be skeptical about old cultural beliefs and look for other sources of knowledge. Meanwhile, other studies have found an association of good knowledge with female gender. ${ }^{5,32}$ A study in KSA found a lack of significant association between teachers' age or gender with their knowledge about epilepsy. ${ }^{21}$

The defects in knowledge found in this study and similar previous studies highlight the importance of launching educational programs for epilepsy to school teachers.

As regards the attitudes of teachers towards epileptic children, we found that two thirds agreed that they would not treat epileptic children as their peers. Similar attitudes were reported by previous studies which showed a considerable percentage of teachers refusing to allow their children to play with epileptic patients $(38.4 \%){ }^{24}$ or to have them in their classrooms $(25-32.2 \%) .{ }^{21,}{ }^{24}$ Improved educational programs should be able to reduce misconceptions and fears about epilepsy, and thereby minimize the effects of the associated social stigma. ${ }^{33}$

The fear of seizures and rejection of epileptic children may contributing to the problem of not knowing how to manage children with epilepsy. ${ }^{34}$ Most teachers in the current study $(71.3 \%)$ were willing to provide first aid during an epileptic fit. However, a study in Thailand showed that half the respondents used improper and potentially harmful measures while providing aid. ${ }^{35}$ Also, in a study in Italy, $66 \%$ of the teachers declared they were unable to manage a seizing child. ${ }^{36}$ Moreover, a study in Khamis Mushate ${ }^{20}$ found most of the teachers who witnessed fits of seizures were not able to provide first aid to students as they were not equipped to give care. ${ }^{20}$ Misconceptions on first aid may be related to poor educational programs for epilepsy. Therefore, educational programs for epilepsy must be provided to teachers on routine basis and must include training on first aid measures, in order to improve the quality of life for people with epilepsy. ${ }^{17,37}$

The majority of teachers in our study $(97.7 \%)$ thought that epileptic students should not be prevented from studying, which is in agreement with many previous studies. ${ }^{20,21,38,39}$. This attitude appears to be mainly based on the teachers' belief that epileptic students had normal mental and learning abilities. ${ }^{20,36}$

We did not find significant association between the attitude of teachers and gender. For age, the highest percentage of teachers who were willing to provide first aid during epileptic fits was in those above 45 years old with statistical significance. This may be attributed to their dealing with different kinds of students with chronic diseases during their long teaching experience.

In conclusion, the school teachers in Hail, KSA had misconceptions about the causes of epilepsy and their attitude is generally positive. Educational programs about diseases among school students - particularly epilepsy - must be a part of the routine preparation and training of school teachers; practical training should encompass also the proper technique of first aid measures during epileptic fits.

Table 1:-sociodemographic data of the respondents $(n=342)$.

\begin{tabular}{|l|l|c|c|}
\hline \multicolumn{2}{|c|}{} & $\mathrm{n}$ & $\%$ \\
\hline \multirow{5}{*}{ Age (Years) } & $<25$ & 64 & $18.7 \%$ \\
\cline { 2 - 4 } & $25-35$ & 112 & $32.7 \%$ \\
\cline { 2 - 4 } & $36-45$ & 116 & $33.9 \%$ \\
\cline { 2 - 4 } & $>45$ & 50 & $14.6 \%$ \\
\hline \multirow{3}{*}{ Nationality } & Saudi & 340 & $99.4 \%$ \\
\cline { 2 - 4 } & No-Saudi & 2 & $0.6 \%$ \\
\hline \multirow{3}{*}{ Gender } & Female & 234 & $68.4 \%$ \\
\cline { 2 - 4 } & Male & 108 & $31.6 \%$ \\
\hline
\end{tabular}

Table 2:-previous knowledge about epilepsy $(\mathrm{n}=342)$.

\begin{tabular}{|c|c|c|c|c|c|c|c|}
\hline & All & \multicolumn{4}{|c|}{ Age groups } & \multicolumn{2}{c|}{ Gender } \\
\cline { 3 - 8 } & respondents & $<25$ & $25-35$ & $36-45$ & $>45$ & Female & Male \\
\hline
\end{tabular}




\begin{tabular}{|l|l|c|c|c|c|c|c|c|c|c|c|c|c|c|c|}
\hline & & $\mathrm{n}$ & $\%$ & $\mathrm{n}$ & $\%$ & $\mathrm{~N}$ & $\%$ & $\mathrm{n}$ & $\%$ & $\mathrm{n}$ & $\%$ & $\mathrm{n}$ & $\%$ & $\mathrm{n}$ & $\%$ \\
\hline $\begin{array}{l}\text { Have you } \\
\text { heard before } \\
\begin{array}{l}\text { about } \\
\text { epilepsy? }\end{array}\end{array}$ & No & 4 & $1.2 \%$ & 2 & $3.1 \%$ & 2 & $1.8 \%$ & 0 & $0.0 \%$ & 0 & $0.0 \%$ & 2 & $0.9 \%$ & 2 & $1.9 \%$ \\
\hline & Yes & 338 & $98.8 \%$ & 62 & $96.9 \%$ & 110 & $98.2 \%$ & 116 & $100.0 \%$ & 50 & $100.0 \%$ & 232 & $99.1 \%$ & 106 & $98.1 \%$ \\
\hline
\end{tabular}

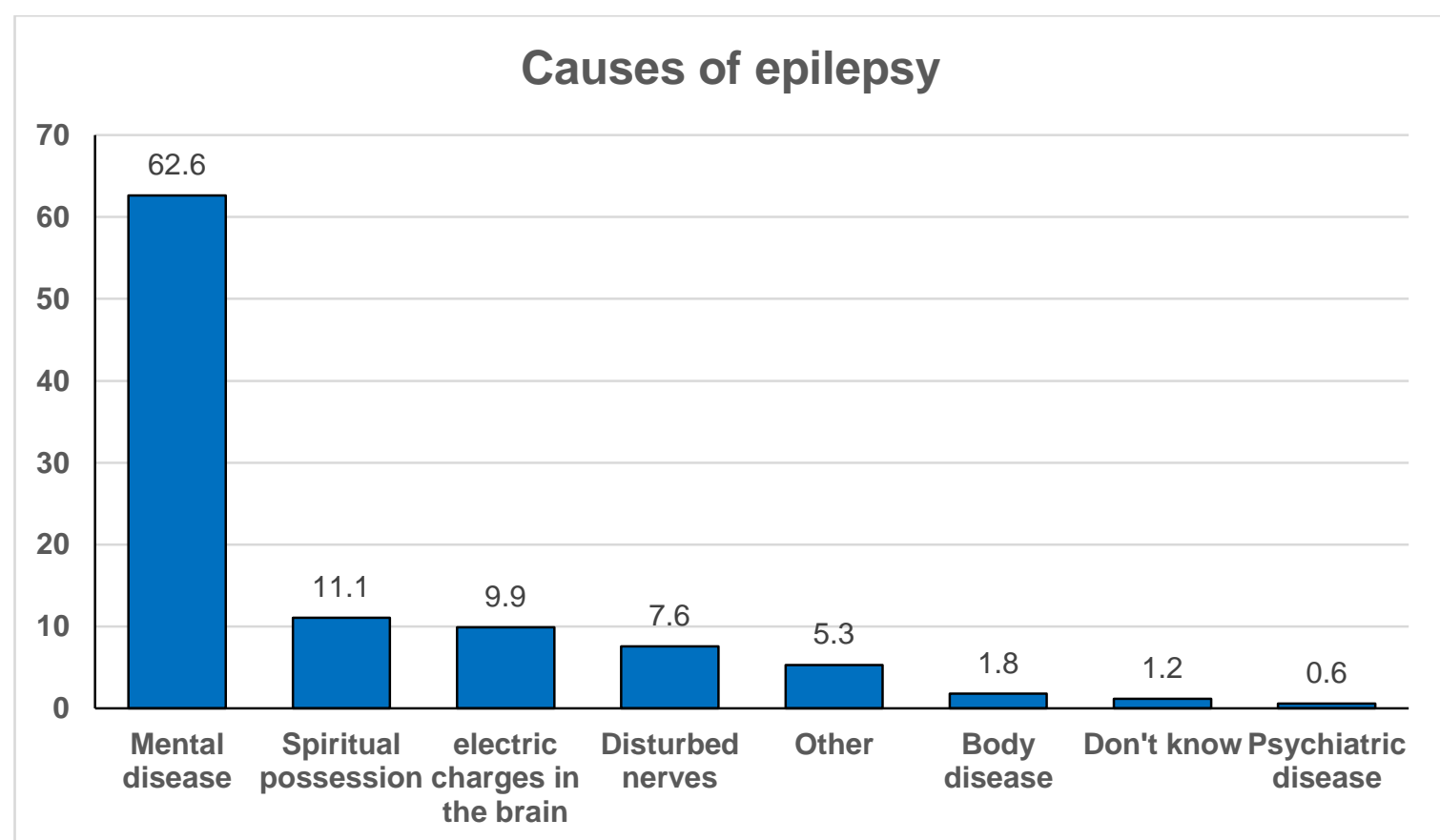

Figure 1:-causes of epilepsy as given by the respondents $(n=342)$.

Table 3:-Knowledge of the respondents about causes of epilepsy.

\begin{tabular}{|c|c|c|c|c|c|c|c|c|c|c|c|c|c|c|c|}
\hline & \multirow{2}{*}{\multicolumn{2}{|c|}{$\begin{array}{c}\text { All } \\
\text { respondent } \\
\text { s }\end{array}$}} & \multicolumn{8}{|c|}{ Age (Years) } & \multicolumn{4}{|c|}{ Gender } \\
\hline & & & & \multicolumn{2}{|c|}{$<25$} & \multicolumn{2}{|c|}{$25-35$} & \multicolumn{2}{|c|}{$36-45$} & \multicolumn{2}{|c|}{$>45$} & \multicolumn{2}{|c|}{ Female } & \multicolumn{2}{|c|}{ Male } \\
\hline & & $\mathrm{n}$ & $\%$ & $\mathrm{n}$ & $\%$ & $\mathrm{n}$ & $\%$ & $\mathrm{n}$ & $\%$ & $\mathrm{n}$ & $\%$ & $\mathrm{n}$ & $\%$ & $\mathrm{n}$ & $\%$ \\
\hline \multirow[t]{5}{*}{$\begin{array}{l}\text { Epileps } \\
\mathrm{y} \text { is }\end{array}$} & $\begin{array}{c}\text { Spiritua } \\
1 \\
\text { possessi } \\
\text { on } \\
\end{array}$ & 36 & $\begin{array}{c}11.6 \\
\%\end{array}$ & 4 & $6.5 \%$ & 14 & $\begin{array}{c}13.5 \\
\%\end{array}$ & 8 & $7.8 \%$ & $\begin{array}{l}1 \\
0\end{array}$ & $\begin{array}{c}23.8 \\
\%\end{array}$ & 24 & $\begin{array}{c}11.4 \\
\%\end{array}$ & 12 & $\begin{array}{c}12.0 \\
\%\end{array}$ \\
\hline & $\begin{array}{c}\text { Disturb } \\
\text { ed } \\
\text { nerves }\end{array}$ & 26 & $8.4 \%$ & 6 & $9.7 \%$ & 10 & $9.6 \%$ & 6 & $5.9 \%$ & 4 & $9.5 \%$ & 18 & $8.6 \%$ & 8 & $8.0 \%$ \\
\hline & $\begin{array}{c}\text { Electric } \\
\text { charges } \\
\text { in the } \\
\text { brain }\end{array}$ & 34 & $\begin{array}{c}11.0 \\
\%\end{array}$ & 0 & $0.0 \%$ & 14 & $\begin{array}{c}13.5 \\
\%\end{array}$ & 16 & $\begin{array}{c}15.7 \\
\%\end{array}$ & 4 & $9.5 \%$ & 24 & $\begin{array}{c}11.4 \\
\%\end{array}$ & 10 & $\begin{array}{c}10.0 \\
\%\end{array}$ \\
\hline & $\begin{array}{l}\text { Mental } \\
\text { disease }\end{array}$ & $\begin{array}{c}21 \\
4\end{array}$ & $\begin{array}{c}69.0 \\
\%\end{array}$ & $\begin{array}{l}5 \\
2\end{array}$ & $\begin{array}{c}83.9 \\
\%\end{array}$ & 66 & $\begin{array}{c}63.5 \\
\%\end{array}$ & 72 & $\begin{array}{c}70.6 \\
\%\end{array}$ & $\begin{array}{l}2 \\
4\end{array}$ & $\begin{array}{c}57.1 \\
\%\end{array}$ & $\begin{array}{c}14 \\
4\end{array}$ & $\begin{array}{c}68.6 \\
\%\end{array}$ & 70 & $\begin{array}{c}70.0 \\
\%\end{array}$ \\
\hline & p-value & \multicolumn{10}{|c|}{$0.008 *$} & \multicolumn{4}{|c|}{0.979} \\
\hline \multirow{3}{*}{$\begin{array}{l}\text { Do you } \\
\text { think } \\
\text { epilepsy } \\
\text { is a }\end{array}$} & No & $\begin{array}{c}34 \\
0\end{array}$ & $\begin{array}{c}99.4 \\
\%\end{array}$ & $\begin{array}{l}6 \\
4\end{array}$ & $\begin{array}{c}100.0 \\
\%\end{array}$ & $\begin{array}{c}11 \\
0\end{array}$ & $\begin{array}{c}98.2 \\
\%\end{array}$ & $\begin{array}{c}11 \\
6\end{array}$ & $\begin{array}{c}100.0 \\
\%\end{array}$ & $\begin{array}{l}5 \\
0\end{array}$ & $\begin{array}{c}100.0 \\
\%\end{array}$ & $\begin{array}{c}23 \\
2\end{array}$ & $\begin{array}{c}99.1 \\
\%\end{array}$ & $\begin{array}{c}10 \\
8\end{array}$ & $\begin{array}{c}100.0 \\
\%\end{array}$ \\
\hline & Yes & 2 & $0.6 \%$ & 0 & $0.0 \%$ & 2 & $1.8 \%$ & 0 & $0.0 \%$ & 0 & $0.0 \%$ & 2 & $0.9 \%$ & 0 & $0.0 \%$ \\
\hline & p-value & \multicolumn{10}{|c|}{0.413} & \multicolumn{4}{|c|}{0.841} \\
\hline
\end{tabular}




\begin{tabular}{|c|c|c|c|c|c|c|c|c|c|c|c|c|c|c|}
\hline $\begin{array}{l}\text { contagi } \\
\text { ous } \\
\text { disease? }\end{array}$ & & & & & & & & & & & & & & \\
\hline Total & $\begin{array}{c}34 \\
2\end{array}$ & $\begin{array}{c}100.0 \\
\%\end{array}$ & $\begin{array}{l}6 \\
4\end{array}$ & $\begin{array}{c}100.0 \\
\%\end{array}$ & $\begin{array}{c}11 \\
2\end{array}$ & $\begin{array}{c}100.0 \\
\%\end{array}$ & $\begin{array}{c}11 \\
6\end{array}$ & $\begin{array}{c}100.0 \\
\%\end{array}$ & $\begin{array}{l}5 \\
0\end{array}$ & $\begin{array}{c}100.0 \\
\%\end{array}$ & $\begin{array}{c}23 \\
4\end{array}$ & $\begin{array}{c}100.0 \\
\%\end{array}$ & $\begin{array}{c}10 \\
8\end{array}$ & $\begin{array}{c}100.0 \\
\%\end{array}$ \\
\hline
\end{tabular}

Table 4:-The attitude of respondents towards epileptic students $(n=342)$.

\begin{tabular}{|c|c|c|c|c|c|c|c|c|c|c|c|c|c|c|c|}
\hline & \multicolumn{10}{|c|}{ Age (Years) } & \multicolumn{4}{|c|}{ Gender } \\
\hline & & \multicolumn{2}{|c|}{$\begin{array}{c}\text { All } \\
\text { respondents }\end{array}$} & \multicolumn{2}{|c|}{$<25$} & \multicolumn{2}{|c|}{$25-35$} & \multicolumn{2}{|c|}{$36-45$} & \multicolumn{2}{|c|}{$>45$} & \multicolumn{2}{|c|}{ Female } & \multicolumn{2}{|c|}{ Male } \\
\hline & & $\mathrm{n}$ & $\%$ & $\mathrm{n}$ & $\%$ & $\mathrm{n}$ & $\%$ & $\mathrm{n}$ & $\%$ & $\mathrm{n}$ & $\%$ & $\mathrm{n}$ & $\%$ & $\mathrm{n}$ & $\%$ \\
\hline \multirow{3}{*}{$\begin{array}{l}\text { Do you } \\
\text { treat } \\
\text { epilepti } \\
\text { c } \\
\text { student } \\
\text { s as you } \\
\text { treat } \\
\text { their } \\
\text { peers }\end{array}$} & No & $\begin{array}{l}21 \\
2\end{array}$ & $\begin{array}{l}62.0 \\
\%\end{array}$ & $\begin{array}{l}4 \\
8\end{array}$ & $\begin{array}{l}75.0 \\
\%\end{array}$ & 66 & $\begin{array}{l}58.9 \\
\%\end{array}$ & 72 & $\begin{array}{l}62.1 \\
\%\end{array}$ & $\begin{array}{l}2 \\
6\end{array}$ & $\begin{array}{l}52.0 \\
\%\end{array}$ & $\begin{array}{l}14 \\
4\end{array}$ & $\begin{array}{l}61.5 \\
\%\end{array}$ & 68 & $\begin{array}{l}63.0 \\
\%\end{array}$ \\
\hline & Yes & $\begin{array}{l}13 \\
0 \\
\end{array}$ & $\begin{array}{l}38.0 \\
\%\end{array}$ & $\begin{array}{l}1 \\
6 \\
\end{array}$ & $\begin{array}{l}25.0 \\
\%\end{array}$ & 46 & $\begin{array}{l}41.1 \\
\%\end{array}$ & 44 & $\begin{array}{l}37.9 \\
\%\end{array}$ & $\begin{array}{l}2 \\
4 \\
\end{array}$ & $\begin{array}{l}48.0 \\
\%\end{array}$ & 90 & $\begin{array}{l}38.5 \\
\%\end{array}$ & 40 & $\begin{array}{l}37.0 \\
\%\end{array}$ \\
\hline & $\begin{array}{l}\text { p- } \\
\text { valu } \\
\mathrm{e}\end{array}$ & \multicolumn{10}{|c|}{0.063} & \multicolumn{4}{|c|}{0.812} \\
\hline \multirow{3}{*}{$\begin{array}{l}\text { Would } \\
\text { you } \\
\text { provide } \\
\text { first aid } \\
\text { for } \\
\text { epilepti } \\
\text { c } \\
\text { patients } \\
\text { during } \\
\text { an } \\
\text { epilepti } \\
\text { c fit }\end{array}$} & No & 98 & $\begin{array}{l}28.7 \\
\%\end{array}$ & $\begin{array}{l}1 \\
6\end{array}$ & $\begin{array}{l}25.0 \\
\%\end{array}$ & 44 & $\begin{array}{l}39.3 \\
\%\end{array}$ & 30 & $\begin{array}{l}25.9 \\
\%\end{array}$ & 8 & $\begin{array}{l}16.0 \\
\%\end{array}$ & 70 & $\begin{array}{l}29.9 \\
\%\end{array}$ & 28 & $\begin{array}{l}25.9 \\
\%\end{array}$ \\
\hline & Yes & $\begin{array}{l}24 \\
4\end{array}$ & $\begin{array}{l}71.3 \\
\%\end{array}$ & $\begin{array}{l}4 \\
8\end{array}$ & $\begin{array}{l}75.0 \\
\%\end{array}$ & 68 & $\begin{array}{l}60.7 \\
\%\end{array}$ & 86 & $\begin{array}{l}74.1 \\
\%\end{array}$ & $\begin{array}{l}4 \\
2\end{array}$ & $\begin{array}{l}84.0 \\
\%\end{array}$ & $\begin{array}{l}16 \\
4\end{array}$ & $\begin{array}{l}70.1 \\
\%\end{array}$ & 80 & $\begin{array}{l}74.1 \\
\%\end{array}$ \\
\hline & $\begin{array}{l}\text { p- } \\
\text { valu } \\
\text { e }\end{array}$ & \multicolumn{10}{|c|}{$0.012^{*}$} & \multicolumn{4}{|c|}{0.448} \\
\hline \multirow{3}{*}{$\begin{array}{l}\text { Do you } \\
\text { think } \\
\text { that } \\
\text { epilepti } \\
\text { c } \\
\text { student } \\
\text { s } \\
\text { should } \\
\text { be } \\
\text { prevent } \\
\text { ed from } \\
\text { studyin } \\
\text { g }\end{array}$} & No & $\begin{array}{l}33 \\
4\end{array}$ & $\begin{array}{l}97.7 \\
\%\end{array}$ & $\begin{array}{l}6 \\
2\end{array}$ & $\begin{array}{l}96.9 \\
\%\end{array}$ & $\begin{array}{l}10 \\
8\end{array}$ & $\begin{array}{l}96.4 \\
\%\end{array}$ & $\begin{array}{l}11 \\
6\end{array}$ & $\begin{array}{l}100.0 \\
\%\end{array}$ & $\begin{array}{l}4 \\
8\end{array}$ & $\begin{array}{l}96.0 \\
\%\end{array}$ & $\begin{array}{l}22 \\
8\end{array}$ & $\begin{array}{l}97.4 \\
\%\end{array}$ & $\begin{array}{l}10 \\
6\end{array}$ & $\begin{array}{l}98.1 \\
\%\end{array}$ \\
\hline & Yes & 8 & $2.3 \%$ & 2 & $3.1 \%$ & 4 & $3.6 \%$ & 0 & $0.0 \%$ & 2 & $4.0 \%$ & 6 & $2.6 \%$ & 2 & $1.9 \%$ \\
\hline & $\begin{array}{l}\text { p- } \\
\text { valu } \\
\mathrm{e}\end{array}$ & \multicolumn{10}{|c|}{0.097} & \multicolumn{4}{|c|}{0.984} \\
\hline \multicolumn{2}{|l|}{ Total } & $\begin{array}{c}34 \\
2\end{array}$ & $\begin{array}{c}100.0 \\
\%\end{array}$ & $\begin{array}{l}6 \\
4\end{array}$ & $\begin{array}{c}100.0 \\
\%\end{array}$ & $\begin{array}{c}11 \\
2\end{array}$ & $\begin{array}{c}100.0 \\
\%\end{array}$ & $\begin{array}{c}11 \\
6\end{array}$ & $\begin{array}{c}100.0 \\
\%\end{array}$ & $\begin{array}{l}5 \\
0\end{array}$ & $\begin{array}{c}100.0 \\
\%\end{array}$ & $\begin{array}{c}23 \\
4\end{array}$ & $\begin{array}{c}100.0 \\
\%\end{array}$ & $\begin{array}{c}10 \\
8\end{array}$ & $\begin{array}{c}100.0 \\
\%\end{array}$ \\
\hline
\end{tabular}

\section{References:-}

1. WHO. Fact Sheet No. 999 Available: http://www.who.int/mediacentre/factsheets/fs999/en/index.html. Accessed 10 January 2019, 2019.

2. Al-Khateeb JM, Al-Khateeb AJ. Research on psychosocial aspects of epilepsy in Arab countries: a review of literature. Epilepsy \& behavior. 2014;31:256-262.

3. Al Rajeh S, Awada A, Bademosi O, et al. The prevalence of epilepsy and other seizure disorders in an Arab population: a community-based study. Seizure-European Journal of Epilepsy. 2001;10(6):410-414. 
4. Kobau R, Price P. Knowledge of Epilepsy and Familiarity with This Disorder in the U.S. Population: Results from the 2002 HealthStyles Survey. Epilepsia. 2003;44(11):1449-1454.

5. Bishop M, Boag EM. Teachers' knowledge about epilepsy and attitudes toward students with epilepsy: results of a national survey. Epilepsy \& Behavior. 2006;8(2):397-405.

6. Toli T, Sourtzi P, Tsoumakas K, et al. Association between knowledge and attitudes of educators towards epilepsy and the risk of accidents in Greek schools. Epilepsy \& Behavior. 2013;27(1):200-203.

7. Dalrymple J, Appleby J. Cross sectional study of reporting of epileptic seizures to general practitioners. BMJ. 2000;320(7227):94-97.

8. Nubukpo P, Preux PM, Clement JP, et al. [Comparison of sociocultural attitudes towards epilepsy in Limousin (France), in Togo and in Benin (Africa)]. Med Trop (Mars). 2003;63(2):143-150.

9. WHO, International League Against Epilepsy, International Bureau for Epilepsy. Epilepsy Care in the World. 2005. WHO 2005.

10. Ngugi AK, Bottomley C, Kleinschmidt I, et al. Estimation of the burden of active and life-time epilepsy: a meta-analytic approach. Epilepsia. 2010;51(5):883-890.

11. Asato MR, Doss JL, Plioplys S. Clinic-friendly screening for cognitive and mental health problems in schoolaged youth with epilepsy. Epilepsy \& Behavior. 2015;48:97-102.

12. Szemere E, Jokeit H. Quality of life is social-Towards an improvement of social abilities in patients with epilepsy. Seizure. 2015;26:12-21.

13. Hun C, Hok T, Ros S, et al. Epilepsy: Some controversies, some knowledge and some experience from Cambodia. Neurology India. 2014;62(6):606.

14. England MJ, Liverman CT, Schultz AM, et al. Epilepsy across the spectrum: Promoting health and understanding.: A summary of the Institute of Medicine report. Epilepsy \& Behavior. 2012;25(2):266-276.

15. May TW, Pfäfflin M. The Efficacy of an Educational Treatment Program for Patients with Epilepsy (MOSES): Results of a Controlled, Randomized Study. Epilepsia. 2002;43(5):539-549.

16. Hsieh LP, Chiou HH. Comparison of epilepsy and asthma perception among preschool teachers in Taiwan. Epilepsia. 2001;42(5):647-650.

17. Ojinnaka NC. Teachers' perception of epilepsy in Nigeria: a community-based study. Seizure-European Journal of Epilepsy. 2002;11(6):386-391.

18. Birbeck GL, Chomba E, Atadzhanov M, et al. Zambian teachers: What do they know about epilepsy and how can we work with them to decrease stigma? Epilepsy \& Behavior. 2006;9(2):275-280.

19. Obeid T, Abulaban A, Al-Ghatani F, et al. Possession by 'Jinn'as a cause of epilepsy (Saraa): a study from Saudi Arabia. Seizure. 2012;21(4):245-249.

20. Alqahtani JM. Knowledge and practice of schoolteachers towards students with epilepsy in Khamis Mushate, Southern Saudi Arabia. Journal of family \& community medicine. 2015;22(3):163-168.

21. Abulhamail AS, Al-Sulami FE, Alnouri MA, et al. Primary school teacher's knowledge and attitudes toward children with epilepsy. Seizure. 2014;23(4):280-283.

22. Choi-Kwon S, Park K, Lee H, et al. Familiarity with, knowledge of, and attitudes toward epilepsy in residents of Seoul, South Korea. Acta Neurologica Scandinavica. 2004;110(1):39-45.

23. Bekiroğlu N, Özkan R, Gürses C, et al. A study on awareness and attitude of teachers on epilepsy in Istanbul. Seizure. 2004;13(7):517-522.

24. Thacker AK, Verma AM, Ji R, et al. Knowledge awareness and attitude about epilepsy among schoolteachers in India. Seizure. 2008;17(8):684-690.

25. Gzirishvili N, Kasradze S, Lomidze G, et al. Knowledge, attitudes, and stigma towards epilepsy in different walks of life: a study in Georgia. Epilepsy \& Behavior. 2013;27(2):315-318.

26. Mustapha A, Odu O, Akande O. Knowledge, attitudes and perceptions of epilepsy among secondary school teachers in Osogbo South-West Nigeria: a community based study. Nigerian journal of clinical practice. 2013;16(1):12-18.

27. Bhesania NH, Rehman A, Savul IS, et al. Knowledge, attitude and practices of school teachers towards epileptic school children in Karachi, Pakistan. Pakistan journal of medical sciences. 2014;30(1):220.

28. Karimi N, Heidari M. Knowledge and attitudes toward epilepsy among school teachers in West of Iran. Iranian journal of neurology. 2015;14(3):130.

29. Majeed A. How Islam changed medicine. BMJ. 2005;331(7531):1486-1487.

30. Falagas ME, Zarkadoulia EA, Samonis G. Arab science in the golden age (750-1258 CE) and today. The FASEB Journal. 2006;20(10):1581-1586.

31. Khalifa N, Hardie T. Possession and jinn. Journal of the Royal Society of Medicine. 2005;98(8):351-353. 
32. Bishop M, Slevin B. Teachers' attitudes toward students with epilepsy: results of a survey of elementary and middle school teachers. Epilepsy \& Behavior. 2004;5(3):308-315.

33. Fernandes PT, Noronha AL, Araújo U, et al. Teachers perception about epilepsy. Arquivos de Neuropsiquiatria. 2007;65:28-34.

34. Fernandes PT, Souza EAPd. Perception of epilepsy stigma in fundamental school teachers. Estudos de Psicologia (Natal). 2004;9(1):189-195.

35. Kankirawatana P. Epilepsy awareness among school teachers in Thailand. Epilepsia. 1999;40(4):497-501.

36. Mecarelli O, Capovilla G, Romeo A, et al. Knowledge and attitudes toward epilepsy among primary and secondary schoolteachers in Italy. Epilepsy \& Behavior. 2011;22(2):285-292.

37. Millogo A, Siranyan AS. Knowledge of epilepsy and attitudes towards the condition among schoolteachers in Bobo-Dioulasso (Burkina Faso). Epileptic Disorders. 2004;6(1):21-26.

38. Kim M-K, Kim I-K, Kim B-C, et al. Positive trends of public attitudes toward epilepsy after public education campaign among rural korean residents. Journal of Korean medical science. 2003;18(2):248.

39. Dekker P, Organization WH. Epilepsy: A manual for medical and clinical officers in Africa. 2002. 